Article

\title{
Exploring the Determinants of Financial Structure in the Technology Industry: Panel Data Evidence from the New York Stock Exchange Listed Companies
}

\author{
Georgeta Vintilă, Ştefan Cristian Gherghina *(i) and Diana Alexandra Toader \\ Department of Finance, The Bucharest University of Economic Studies, 6 Piata Romana, 010374 Bucharest, \\ Romania; vintilageorgeta@yahoo.fr (G.V.); diana.tda29@gmail.com (D.A.T.) \\ * Correspondence: stefan.gherghina@fin.ase.ro; Tel.: +40-741-140-737
}

Received: 10 September 2019; Accepted: 20 October 2019; Published: 22 October 2019

\begin{abstract}
This paper aims to analyze the influencing factors on the financial structure of 51 companies listed on the New York Stock Exchange, in the technology industry, from 2005-2018. The objective is to see the impact of independent company-specific variables such as company size, tangibility of assets, growth opportunity, effective tax rate, current liquidity, depreciation, stock rotation, financial return, working capital, price to book value, price to earnings ratio, as well as the impact of governance variables and macroeconomic variables such as inflation rate, interest rate, market size, gross domestic product per capita. Using panel data and multiple linear regressions, we analyze the relationship between the independent variables listed above and the dependent variables, namely the total debt ratio, the long-term debt ratio and the short-term debt ratio. The results of the analysis showed that variables such as size, tangibility, liquidity, profitability have a significant influence on the dependent variables in accordance with the theories regarding the capital structure.
\end{abstract}

Keywords: financial structure; panel data; regression analysis

\section{Introduction}

The first decade of the 21st century has undergone major changes in the recession and boom periods. These cycles in the economy have had an important impact on the value of the company. Seeing as how an enterprise is also evaluated from the point of view of investments, both those of the past and those of the future, and in order to support these investments, it is essential to choose a financial mix. The financial decision depends on the dynamics of the business environment, whether it is in a period of growth or decrease. When a financial crisis occurs, the creditors dictate their preferred method of financing to companies. If a manager searches for capital, he should be aware of the preferences of investors and precisely respond to the conservative behavior of creditors, because they face a big dilemma, to invest or not. The firm's manager should understand their dilemma and try to attract the confidence of the investors through the firm-specific features. The effects of the Euro Crisis resulted significantly negatively related to leverage in the study of Moradi and Paulet (2019). During the financial crisis, firms which are vulnerable to the shocks in the financial markets absorb the negative impact earlier than other firms. Hence, financial difficulties can lead to bankruptcy and can be the result of wrong decisions in choosing the financial structure. The financial structure is the result of some decisions that managers take in order to support long-term investments, identifying appropriate sources of financing to contribute to the optimal development of the company. Investments were affected after the economic crisis in 2008 in different ways, depending on firm's debt structure and whether firms had access to the public debt market. Iwaki (2019) found that accessibility to the public debt market, as well as, the differences in debt structures have an important influence in investment. 
The author underlined the fact that bank-dependent firms faced more underinvestment after crisis than firms with access to public debt market. Thus, the capital structure is a fundamental element of the organization. Financial resources can be divided into two broad categories, namely, equity and debt, and the financial structure can be defined as a merger between the two, more precisely, a ratio in which they are allocated. An optimal combination of these results in a reduction in the price of capital.

The empirical literature highlighted the effects of firm-specific and country-specific factors on firm leverage, such as size, growth, asset tangibility, profitability, tax shields, liquidity, earnings volatility and interest rate, inflation rate, gross domestic product etc. Capital structure decisions are affected by the firm's own characteristics and country characteristics. Previous research demonstrated that the effects of capital structure determinants are not equal across countries. Ramli et al. (2019) emphasized that the impact of firm-specific factors and country-specific differ in terms of significance, sign and intensity level in Malaysia and Indonesia. Industry-specific factors have also a contribution to capital structure decisions. Li and Islam (2019) showed that industry-specific factors can both directly and indirectly affect the capital structure choice. In terms of direct impacts, the authors showed that GDP significantly influences the capital structure. In terms of indirect impacts, their findings showed that companies tend to be more leveraged, if they operate in economically significant industries.

It is important to study which factors have an influence on the financial structure, as this in turn has an influence on the economic performance of the company. Identifying an optimal financial structure is relevant to reduce risk and increase performance. An imbalance in loans and their ability to generate financial efficiency can lead to bankruptcy. Therefore, it is vital to have a balanced report on the use of equity and borrowed capital as sources of financing, but also to know the factors and their influence in order to make a precise delimitation of the proportions. The database consists of 51 companies from the technology industry listed on the New York Stock Exchange. The companies in this sector are constantly evolving and they contribute to the change of human culture and it seems relevant to study which factors have an influence on financial structure of these companies. The studied period of time 2005-2018 is also relevant because it includes the recession period as well as the post-recession period, when the companies had to take important financial decisions in order to survive in front of the crisis

The rest of the paper proceeds as follows. Section 2 discusses the existing theories and related literature. Section 3 presents the database, selected variables and quantitative techniques. Section 4 reveals the empirical findings. The last section concludes the study.

\section{Literature Review}

The first theories were formulated by Modigliani and Miller (1958), who wrote in an early article that the structure of capital does not influence the value of the firm. In their article MM started from the premises that the market is perfect and there are no factors that significantly influence the market, taxation does not exist, trading costs and bankruptcy are absent. In reality this theory is not valid because the perfect market does not exist and taxation is present. After the criticisms received regarding the first theory, a few years later, Modigliani and Miller (1963) considered the possibility of revising the first hypotheses, introducing taxation and developing the first theory. MM acknowledged that taxation has an effect on debt and capital and has some advantages since interest is deductible.

Agent theory developed by Jensen and Meckling (1976) captures the idea of agency costs that arise as a result of conflicts between managers, shareholders, and creditors. These conflicts are supposed to arise due to the inconsistency of interests. Managers tend to use the firm's resources in projects that bring more personal benefits than maximizing the value of the company. Shareholders can discourage such a behavior through monitoring and control activities. However, these actions also involve costs, called agency costs. Debt can reduce agency costs and affect the performance of the company at the same time, by determining the managers to act in the interest of the company rather than in their own interest. Thus, the option of a company to be financed through debt reduces the cash flow available at the discretion of managers, reducing agency costs. 
Following the same line of thinking, the trade-off theory takes into account industry-level effects, taxes, bankruptcy costs and agency issues. Kraus and Litzenberger (1973) are the ones who grounded this theory and argue that a firm can determine its financial structure by balancing the costs and benefits related to external financing. In this theoretical approach, the leverage is considered to bring advantages, under certain conditions, and managers prefer to use debt as a source of financing instead of the available internal funds. If a company becomes too indebted, the tax savings will be higher and therefore bankruptcy costs will rise. That is why it is recommended in theory to avoid over-indebtedness and to rationalize the indebtedness index. This theory starts from the premise that there is a positive relationship between the capital structure and the performance of the enterprise.

In contrast to previous theories, the pecking order theory developed by Myers and Majluf (1984) implies an ordering of financing sources, which presents greater flexibility and lower trading costs and is based on information asymmetry between companies and creditors. Due to the fact that the company has more information about the future than the creditors, the need for monitoring increases the borrowing costs, and this encourages companies to finance with their own funds, thus the first source would be internal financing. The second source is the external financing if it is required after the exhaustion of the internal funds, first resorting to the most secure sources, that is to say, the debt, then issues of securities. As soon as the internal funds become available, it is preferable to cancel the debt before maturity. The last source is the capital increase through the issue of shares. Therefore, the pecking order theory suggests that debt has an adverse effect on performance.

Unlike the pecking order theory, where firms use internal funds to eliminate the problems of adverse selection and loss of value, where they cannot show their quality using the financial structure, the signal theory, developed by Ross (1977), which uses the capital structure as a signal of private information, starts from the information asymmetry and underlines that the managers know the truth regarding the distribution of the company's results, but the creditors do not have this information. Investors see a high degree of debt as a signal of performance, because the company is considered to have the ability to repay the debt at maturity. Therefore, by contracting a loan, managers give a signal on the market to potential investors, as well as existing ones.

The market timing theory, developed by Baker and Wurgler (2002), starts from the idea that raising capital by issuing shares depends on market performance. In corporate finance, market timing involves in practice, issuing high-priced shares and repurchasing them at a lower price, in order to benefit from fluctuations in the ratio between the cost of equity and other forms of capital.

From most of the studies I have included in this paper, I have looked at the main indicators that have proved to be of undeniable importance and influence. Among them, indicators such as tangibility, profitability, liquidity and so on can be listed.

\subsection{Tangibility}

A company may choose to have higher debt if it has a high tangibility ratio. A high tangibility ratio will probably also have low financial costs according to the trade-off theory. (Chaklader and Chawla 2016; Cortez and Susanto 2012; Rajan and Zingales 1995; Song 2005) obtained in their papers a positive association between tangibility and indebtedness. (Chittenden et al. 1996; Demirgüç-Kunt and Maksimovic 1999; van der Wijst and Thurik 1993) obtained a negative relationship.

\subsection{Profitability}

A high degree of profitability leads to a decrease in the degree of indebtedness, as it is assumed that firms will resort to indebtedness to prevent managers from spending from the available cash flow. A high level of rentability also means the ability of the company to borrow more easily. (Cortez and Susanto 2012; Krishnan and Moyer 1996; Psillaki and Daskalakis 2009; Rajan and Zingales 1995; Titman and Wessels 1988) obtained a negative association between profitability and indebtedness, while (Alipour et al. 2015; Song 2005) obtained a positive one. Chaklader and Chawla (2016) show an insignificant relationship. 


\subsection{Liquidity}

A high degree of liquidity implies a lower degree of debt. An optimal level of liquidity presumes less requirement for borrowing and external funds, according to pecking order theory and agency theory. In contrast, based on trade-off theory, the companies should ensure an optimal level of liquidity in order to fulfil their engagement. Chadha and Sharma (2015) found that liquidity is statistically insignificant. Alipour et al. (2015) obtained a negative relationship between liquidity and leverage.

\subsection{Size}

It is assumed that there is a positive relationship between firm size and debt, according to trade-off theory, because larger firms are more diversified and tend to have lower variance of profits, allowing them to tolerate higher debt ratios. In contrast, pecking order theory predicts a negative relationship, due to the fact that larger firms deal with lower adverse selection and have the ability to issue equity more easily compared to small businesses. (Chaklader and Chawla 2016; Psillaki and Daskalakis 2009; Rajan and Zingales 1995; Song 2005) achieved a positive association. Alipour et al. (2015) obtained an inverse relationship, concluding that small companies have no option but to resort to bank loans. (Cortez and Susanto 2012; Viviani 2008) found the relationship between size and debt ratio insignificant.

\subsection{Growth}

The pecking order theory states that there is a positive relationship between growth and debt. Companies with high growth rates need sufficient funds to support their investment opportunities and internal funds are unlikely to be enough to support them. Trade-off theory states that there is a negative relationship, assets intangibility of firms with high growth rates implies the risk of losing value in case of financial distress. (Chaklader and Chawla 2016; Psillaki and Daskalakis 2009) showed that the growth variable is statistically insignificant, contrary to (Alipour et al. 2015; Cortez and Susanto 2012) who concluded that the relationship between the growth variable and the dependent variable is significantly negative.

\subsection{Inflation}

Chadha and Sharma (2015) found that inflation is statistically insignificant. Bokpin (2009) obtained a significant relationship. In most cases, firms will resort to internal sources of financing during periods when inflation is high, as this pressure will increase the cost of obtaining capital from creditors.

\subsection{Gross Domestic Product Per Capita}

The improvement of the general economy determines the companies to resort to internal sources of financing to the detriment of external sources. Bokpin (2009) obtained an inverse relationship, contrary to Bas et al. (2010), who obtained a significant positive relationship with the debt, explaining that an economic growth determines the companies to be more willing to contract the loans in order to be able to support the new investments.

\subsection{The Interest Rate}

The effect of the interest rate on the financing option is certainly not to be neglected, because the costs of external financing reflect the weighted average cost of capital of firms. Increasing the interest rate positively influences the choice of short-term funds, rather than opting for long-term debt. (Bas et al. 2010; Bokpin 2009) obtained a positive but statistically insignificant relationship between the two.

\subsection{Effective Tax Rate}

A company that has a high effective rate of corporate income tax will seek external financing to benefit from the tax deduction of interest expenses. Alipour et al. (2015) show a positive association. 


\subsection{Risk}

Trade-off theory states that risky businesses should not be highly levered, according to this theory, there is a negative relationship between risk and debt. From pecking order theory perspective there is also a negative association between operating risk and debt. A company with high volatility in earnings is more likely to face a debt burden and to go bankrupt. Psillaki and Daskalakis (2009) obtained a negative relationship.

\subsection{Corporate Governance Variables (Board Size, CEO Status)}

There is a positive relationship between board size and debt. Companies with large boards are much more capable to find external funds and at the same time, financial institutions are more confident while lending firms with large size boards. Sheikh and Wang (2012) obtained a positive and statistically significant relationship between board size and debt. CEO status refers to duality of the CEO, namely when the CEO of the company serve as chairman in the board. It is expected that there is a conflict of interest when the same person serves in both positions, because that gives too much power and control. Buvanendra et al. (2017) obtained a negative statistically significant relationship between CEO duality and debt.

In all the abovementioned studies, there can be observed a pattern to be observed, since all included independent variables are related to the structure of assets, profitability, taxation. Only in a few works there were macroeconomic variables included such as inflation rate, interest rate or even the gross domestic product. The results are similar and showed that the tangibility, the profitability, the increase in size, for example, are factors with a significant influence on the financial structure. There were also variables that proved to be insignificant, but these results are also influenced by the chosen database and the processing of data in advance. Theoretically, from a broader perspective, the choice of capital structure must be viewed from three perspectives: the advantage of tax exemption, the risk assumed and the quality and type of assets. This indicates that a low-risk, high-profit firm with few intangible assets and robust growth opportunities should find a relatively high ratio between debt and equity less attractive.

\section{Data and Methodology}

The process of forming the database for analyzing the influencing factors on the financial structure consisted in the initial collection of the financial data of 75 companies listed on the New York Stock Exchange, companies that are part of the technology industry. Because there was not enough data for the analyzed period, 2005-2018, the database consists of only 51 companies. The financial data was taken from the Thomson Reuters databases, respectively The World Bank, from which the independent variables such as inflation rate, interest rate, gross domestic product per capita were taken.

\subsection{Database Construction and Variables Presentation}

The dependent variables included in the analysis are included in Table 1 . I chose three dependent variables, which explain to a certain extent the financial structure, namely, the rate of total debt, the rate of long-term and short-term debt. These debt ratios show which proportion of assets are financed by debt. A high value of these ratios reveals the leverage of the company, and also the financial risk. Debt ratios vary across industries, businesses with intensive capital such as transportation sectors or telecommunications have higher debt than other industries such as technology sector. 
Table 1. Dependent variables included in the empirical study.

\begin{tabular}{cccc}
\hline Variable Name & Symbol & Formula & Authors \\
\hline Total debt rate & TD & Total debts/total assets & $\begin{array}{c}\text { Bokpin (2009), Chaklader and Chawla (2016), Psillaki } \\
\text { and Daskalakis (2009), Su (2010), Viviani (2008) }\end{array}$ \\
\hline Long-term debt rate & LTD & $\begin{array}{c}\text { Long-term debt/total } \\
\text { assets }\end{array}$ & $\begin{array}{c}\text { Amidu (2007), Eldomiaty and Azim (2008), Ezeoha } \\
\text { (2008), Hall et al. (2004), Titman and Wessels (1988), van } \\
\text { der Wijst and Thurik (1993), Viviani (2008) }\end{array}$ \\
\hline Short-term debt rate & STD & $\begin{array}{c}\text { Short-term debt/total } \\
\text { assets }\end{array}$ & $\begin{array}{c}\text { Amidu (2007), Eldomiaty and Azim (2008), Ezeoha } \\
\text { (2008), Hall et al. (2004), van der Wijst and Thurik (1993) }\end{array}$ \\
\hline
\end{tabular}

Source: Author's own work.

Estimating separate relationships for long-term and short-term debt rates (long-term and short-term debt over total assets) allows for an influence on the maturity of the debt structure as well as the leverage. Total assets are included as a size variable to test scale effects in the ratio of debt to total assets.

Table 2 below shows the independent variables classified according to the level of influence, namely, microeconomic, macroeconomic and corporate governance indicators.

(Barton et al. 1989; Titman and Wessels 1988) agreed that companies with high rates of profit will maintain a low rate of debt, because they are able to generate funds from internal sources, so the profitability indicator was included as a variable. Companies with very high growth rates will seek external sources of funding to support their growth rate. Auerbach (1985) also argues that the leverage is inversely proportional to the growth rate, because the tax deduction of interest expense is not significant for fast-growing firms. Michaelas et al. (1999) found a positive expected growth related to leverage and long-term debt, while (Chittenden et al. 1996; Jordan et al. 1997) found mixed evidence. Graham (1996) concluded that, in general, taxes affect the financial decisions of enterprises, but the impact is not major. Myers (1977) argues that tangible assets, such as fixed assets, can support a higher level of debt compared to intangible assets. Assets can be used as collateral to reduce potential agent costs associated with borrowing (Smith and Warner 1979; Stulz and Johnson 1985). The size of the company plays an important role in determining the financial structure of a company. Researchers have found that large firms are less likely to go bankrupt because they tend to be more diverse than smaller companies (Ang et al. 1982; Marsh 1982; Smith and Warner 1979; Titman and Wessels 1988) report a negative relationship between the debt and the size of the firms. Marsh (1982) argues that small firms, due to their limited access to the capital market, tend to rely heavily on loans. Titman and Wessels (1988) argue that small firms are less reliant on equity because they may face a higher cost per issue unit. Ooi (1999) argues that firms with relatively higher operational risk will have incentives to have a lower leverage than firms with more stable incomes. Öztekin and Flannery (2012) have observed that firms that have more liquid assets can use them as an internal alternative of funds instead of debt. I included four macroeconomic indicators, GDP per capita, inflation rate, interest rate, and market size in the study (Bartholdy and Mateus 2008; Demirgüç-Kunt and Maksimovic 1996, 1999). I also included the GDP per capita because with its growth, the countries become richer and implicitly there are more financing resources. Thus, I expect this indicator to be positively correlated with debt. Inflation provides a perspective on the stability of the national currency. Countries with a high inflation rate are associated with a high degree of uncertainty. In general, loans are nominal value contracts, and the inflation rate influences the value of loans, making them riskier. I expect the inflation rate to be negatively correlated with debt. When the interest rate increases, companies are no longer willing to resort to bank loans, because the cost of the loan is higher. Therefore, I expect the interest rate to be inversely proportional to the debt. The size of the market was included because it indicates how easy it is to access the market. The corporate governance indicators were also included in the empirical study to see if they influence the financial structure. Vintilă and Gherghina (2012) obtained mixed results regarding the relationship between the size of the board and the performance of the company. The paper had a database of 155 US companies listed from different industries and investigated the relationship between corporate governance mechanism, CEO characteristics and 
company performance. It turned out that the number of board members is in a negative relationship with Tobin's $Q$, but in a positive relationship with ROA. From the point of view of the status of the CEO, no results have been obtained that suggest a relationship with the performance of the company, whether or not he is chairman of the board. Therefore, I expect that the size of the board, the status of the CEO and the existence of the committees will not influence the financial structure.

Table 2. Independent variables included in the empirical study.

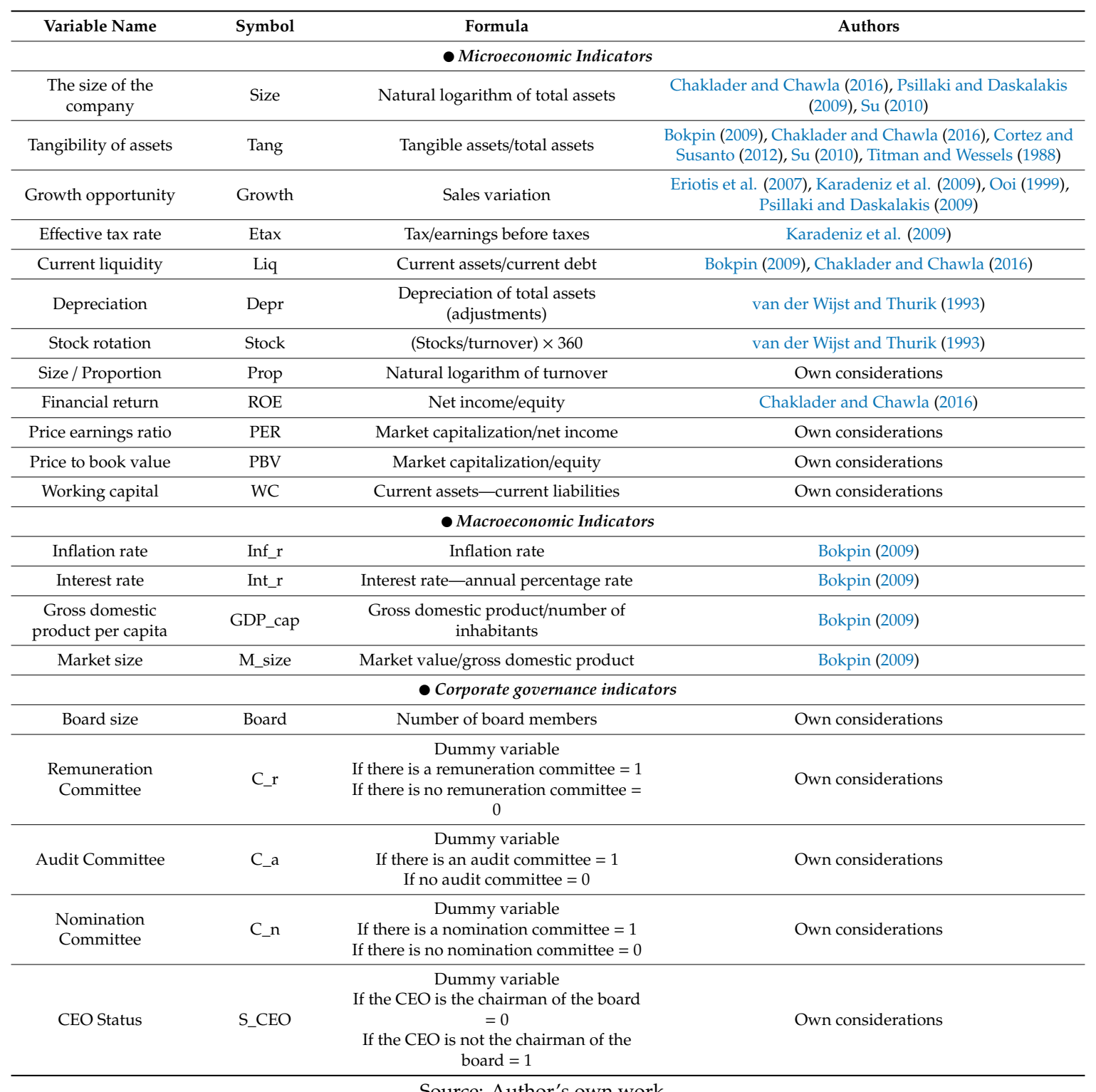

Source: Author's own work.

The general objective is to analyze the factors which have an influence on the financial structure. Firstly, I will start from a set of hypotheses, which will be tested afterwards, in accordance with the studies mentioned above.

Hypothesis 1 (H1). There is a positive relationship between size and debt ratio (Chaklader and Chawla 2016; Cortez and Susanto 2012; Song 2005).

Hypothesis 2 (H2). There is a positive relationship between tangibility and debt ratio (Chaklader and Chawla 2016; Cortez and Susanto 2012; Song 2005). 
Hypothesis 3 (H3). There is a negative relationship between growth opportunity and debt ratio (Alipour et al. 2015; Cortez and Susanto 2012; Psillaki and Daskalakis 2009).

Hypothesis 4 (H4). There is a negative relationship between liquidity and debt ratio (Alipour et al. 2015; Chaklader and Chawla 2016).

Hypothesis 5 (H5). There is a positive relationship between the tax rate and debt ratio (Alipour et al. 2015).

Hypothesis 6 (H6). There is a negative relationship between profitability and debt ratio (Alipour et al. 2015; Chaklader and Chazula 2016; Cortez and Susanto 2012; Nenu et al. 2018).

Hypothesis 7 (H7). There is a negative relationship between inflation rate and debt ratio (Bokpin 2009; Chadha and Sharma 2015; Demirgüç-Kunt and Maksimovic 1999).

Hypothesis 8 (H8). There is a negative relationship between interest rate and debt ratio (Bartholdy and Mateus 2008; Chadha and Sharma 2015; Demirgïç-Kunt and Maksimovic 1999).

Hypothesis 9 (H9). There is a positive relationship between GDP and debt ratio (Demirgüç-Kunt and Maksimovic 1996).

Hypothesis 10 (H10). There is a negative relation between board size and debt ratio (own consideration).

Hypothesis 11 (H11). There is a negative relation between presence of audit committee and debt ratio (own consideration).

Hypothesis 12 (H12). There is a negative relation between presence of nomination committee and debt ratio (own consideration).

Hypothesis 13 (H13). There is a negative relation between presence of remuneration committee and debt ratio (own consideration).

Hypothesis 14 (H14). There is a negative relation between CEO Status and debt ratio (own consideration).

\subsection{Econometric Framework}

The influence factors were studied based on multiple regression model, using the method of least squares, data being structured as panel type:

$$
\begin{aligned}
& \text { Financial_structure }_{i, t}=\alpha_{0}+\alpha_{1} \times \text { Depr }_{i, t}+\alpha_{2} \times P B V_{i, t}+\alpha_{3} \times W C_{i, t}+\alpha_{4} \times \text { Prop }_{i, t}+\alpha_{5} \times R O E_{i, t} \\
& +\alpha_{6} \times \operatorname{Inf}_{-} r_{i, t}+\alpha_{7} \times C_{-} a_{i, t}+\varepsilon_{i, t} \\
& \text { Financial_structure }_{i, t}=\alpha_{0}+\alpha_{1} \times L_{i q_{i, t}}+\alpha_{2} \times \text { Tang }_{i, t}+\alpha_{3} \times M_{-} \text {size }_{i, t}+\alpha_{4} \times G D P \_c a p_{i, t} \\
& +\alpha_{5} \times \text { Int_r } r_{i, t}+\alpha_{6} \times C_{-} n_{i, t}+\alpha_{7} \times S \_C E O_{i, t}+\varepsilon_{i, t} \\
& \text { Financial_structure }_{i, t}=\alpha_{0}+\alpha_{1} \times \text { Growth }_{i, t}+\alpha_{2} \times \text { PER } R_{i, t}+\alpha_{3} \times \text { Stock }_{i, t}+\alpha_{4} \times \text { Size }_{i, t} \\
& +\alpha_{5} \times \operatorname{Etax}_{i, t}+\alpha_{6} \times C_{-} r_{i, t}+\alpha_{7} \times \text { Board }_{i, t}+\varepsilon_{i, t}
\end{aligned}
$$

where Financial_structure $=$ TD, LTD, STD; $\alpha_{0}=$ constant; $\alpha_{1} \ldots \alpha_{7}=$ coefficients of the parameters; $\varepsilon=$ error term; $t=2005 \ldots 2018 ; i=1,2, \ldots, 51$.

The regression models are built based on the correlation matrix. The corporate governance variables are strongly correlated with each other and they were separated in three models. This situation is similar for the size indicator, which was calculated once as natural logarithm from total assets and once as natural logarithm from turnover. A macroeconomic indicator was also included in each model. 


\section{Empirical Findings}

\subsection{Summary Statistics and Correlations}

Table 3 presents the descriptive analysis of the variables. The indebtedness rates of the companies are neither very small nor very high, to signal an alarming situation. The average of long-term debt is $35 \%$, while the average of short-term debt is $21 \%$, so the proportion of long-term debt is higher than that of short-term debt. The maximum values, respectively the minimum, the median and the standard deviation are presented in the table for statistical inferences.

Table 3. Descriptive statistics.

\begin{tabular}{ccccccc}
\hline Variable & Observations & Mean & Median & Maximum & Minimum & Std. Dev. \\
\hline TD & 714 & 0.56 & 0.18 & 11.31 & 0.02 & 1.36 \\
LTD & 714 & 0.35 & 0.16 & 11.28 & 0.00 & 1.19 \\
STD & 714 & 0.21 & 0.11 & 2.92 & 0.02 & 0.29 \\
Growth & 714 & 1.22 & 0.10 & 286 & -0.94 & 15.30 \\
Depr & 714 & $17,427.7$ & 36.50 & 980,101 & 0.10 & $99,342.38$ \\
WC & 714 & $200,976.9$ & 135.40 & $48,789,450$ & $-21,487,305$ & 413,645 \\
Liq & 714 & 2.56 & 1.88 & 34.93 & 0.14 & 3.01 \\
Prop & 714 & 7.31 & 7.01 & 17.36 & -2.30 & 2.85 \\
Size & 714 & 7.52 & 7.18 & 18.60 & 2.19 & 2.84 \\
M_size & 714 & 0.000463 & 0.000448 & 0.000847 & 0.000133 & 0.000105 \\
Board & 714 & 8.55 & 8.00 & 16.00 & 4.00 & 2.20 \\
PBV & 714 & -9.87 & 2.03 & 526.09 & -2843.21 & 190.92 \\
PER & 714 & -155.34 & 15.18 & 5538.66 & $-64,217.32$ & 3067.12 \\
GDB_cap & 714 & $52,104.38$ & 51,556 & 62,996 & 44,026 & 5505.14 \\
Inr_r & 714 & 0.14 & 0.14 & 0.16 & 0.13 & 0.01 \\
Etax & 714 & -0.57 & 0.27 & 6.86 & -511.33 & 19.31 \\
Inf_r & 714 & 0.02 & 0.02 & 0.04 & 0.001 & 0.01 \\
ROE & 714 & -221.10 & 0.10 & 2.43 & $-58,695$ & 3077.75 \\
Stock & 714 & 61.31 & 55 & 629.70 & 0.70 & 51.03 \\
S_Ceo & 714 & 0.78 & 1.00 & 1.00 & 0.00 & 0.41 \\
Tang & 714 & 0.30 & 0.21 & 1.21 & 0.0022 & 0.27 \\
C_a & 714 & 0.75 & 1.00 & 1.00 & 0.00 & 0.43 \\
C_n & 714 & 0.64 & 1.00 & 1.00 & 0.00 & 0.48 \\
C_r & 714 & 0.74 & 1.00 & 1.00 & 0.00 & 0.44 \\
\hline
\end{tabular}

Source: Author's own work.

The rate of financial return is somewhere at $10 \%$ and is negatively correlated with all debt rates, the strongest correlation being with the long-term debt rate. Price to earnings ratio and price to book value are also negatively correlated with debt ratios. Debt can create artificial increases in price to book value. Price to earnings ratio, as well as price to book value, does not help investors in comparisons regarding companies' debts to make certain decisions, although debt has a major impact on company performance, illustrated by the financial leverage effect, that can be both positive or negative.

The average duration of the stock rotation is 66 days, meaning that the products stay about 2 months in stock until they are sold. According to Table 4 there is no significant association between the working capital and the total indebtedness rate, respectively on the long term, but there is a negative correlation between this and the short-term indebtedness rate. There is also a negative correlation between current liquidity and debt ratios, most companies having optimal liquidity, if we look at the median that is around 1 . The technology sector requires a longer period of time to use the products, thus a value less than 1 should not be a negative signal. 
Table 4. Correlation of variables.

\begin{tabular}{|c|c|c|c|c|c|c|c|c|c|c|c|c|c|c|c|c|c|c|c|c|c|c|c|c|}
\hline Variable & $\begin{array}{c}1 \\
\text { TD } \\
\end{array}$ & $\begin{array}{c}2 \\
\text { LTD } \\
\end{array}$ & $\begin{array}{c}3 \\
\text { STD } \\
\end{array}$ & $\begin{array}{c}4 \\
\text { Growth }\end{array}$ & $\begin{array}{c}5 \\
\text { Depr } \\
\end{array}$ & $\begin{array}{c}6 \\
W C\end{array}$ & $\begin{array}{c}7 \\
\text { Liq }\end{array}$ & $\begin{array}{c}8 \\
\text { Size } \\
\end{array}$ & $\begin{array}{c}9 \\
\text { Prop }\end{array}$ & $\begin{array}{c}10 \\
\text { M_Size }\end{array}$ & $\begin{array}{c}11 \\
\text { Board } \\
\end{array}$ & $\begin{array}{c}12 \\
\text { PBV }\end{array}$ & $\begin{array}{c}13 \\
\text { PER } \\
\end{array}$ & $\begin{array}{c}14 \\
\text { GDP_ca }\end{array}$ & $\begin{array}{c}15 \\
\text { apInt_r }\end{array}$ & $\begin{array}{c}16 \\
\text { Etax } \\
\end{array}$ & $\begin{array}{c}17 \\
\text { Inf_r }\end{array}$ & $\begin{array}{c}18 \\
\text { ROE }\end{array}$ & $\begin{array}{c}19 \\
\text { Stock }\end{array}$ & $\begin{array}{c}20 \\
\text { S_CEO }\end{array}$ & $\begin{array}{c}21 \\
\text { Tang }\end{array}$ & $\begin{array}{c}22 \\
C_{-} a\end{array}$ & $\begin{array}{c}23 \\
\text { C_n }\end{array}$ & $\begin{array}{l}24 \\
C_{-} r\end{array}$ \\
\hline 1 & 1 & 0.90 & 0.18 & 0.03 & -0.01 & 0.00 & -0.07 & -0.20 & -0.29 & 0.07 & -0.06 & -0.64 & -0.05 & -0.12 & 0.04 & 0.00 & 0.06 & -0.13 & 0.03 & 0.12 & -0.03 & -0.25 & -0.18 & -0.23 \\
\hline 2 & 0.90 & 1 & 0.23 & 0.03 & -0.02 & 0.00 & -0.08 & -0.23 & -0.31 & 0.10 & -0.04 & -0.52 & -0.32 & -0.14 & 0.05 & 0.00 & 0.07 & -0.25 & 0.04 & 0.12 & -0.06 & -0.28 & -0.21 & -0.26 \\
\hline 3 & 0.18 & 0.23 & 1 & -0.04 & -0.08 & -0.03 & -0.31 & -0.26 & -0.16 & 0.02 & -0.17 & -0.12 & -0.09 & -0.12 & 0.06 & 0.02 & 0.07 & -0.08 & -0.11 & 0.02 & -0.20 & -0.27 & -0.23 & -0.26 \\
\hline 4 & 0.03 & 0.03 & -0.04 & 1 & -0.01 & 0.00 & -0.04 & -0.02 & -0.08 & 0.06 & -0.02 & -0.01 & -0.04 & -0.09 & 0.03 & 0.02 & 0.07 & 0.00 & 0.01 & 0.04 & 0.11 & 0.03 & 0.04 & 0.03 \\
\hline 5 & -0.01 & -0.02 & -0.08 & -0.01 & 1 & 0.36 & 0.03 & 0.64 & 0.59 & 0.35 & 0.28 & 0.01 & 0.01 & 0.11 & 0.03 & 0.01 & -0.03 & 0.01 & -0.16 & -0.01 & -0.14 & 0.01 & -0.16 & 0.01 \\
\hline 6 & 0.00 & 0.00 & -0.03 & 0.00 & 0.36 & 1 & 0.02 & 0.19 & 0.17 & 0.08 & 0.09 & 0.00 & 0.00 & 0.06 & 0.00 & 0.00 & -0.02 & 0.00 & -0.05 & 0.03 & -0.04 & 0.03 & -0.04 & 0.03 \\
\hline 7 & -0.07 & -0.08 & -0.31 & -0.04 & 0.03 & 0.02 & 1 & -0.05 & -0.05 & -0.09 & -0.18 & 0.03 & 0.04 & 0.02 & -0.06 & -0.04 & -0.05 & 0.04 & 0.01 & 0.11 & 0.23 & 0.13 & 0.14 & 0.12 \\
\hline 8 & -0.20 & -0.23 & -0.26 & -0.02 & 0.64 & 0.19 & -0.05 & 1 & 0.95 & 0.63 & 0.56 & 0.10 & 0.07 & 0.15 & -0.01 & 0.01 & -0.06 & 0.08 & -0.16 & -0.20 & -0.02 & 0.15 & 0.01 & 0.14 \\
\hline 9 & -0.29 & -0.31 & -0.16 & -0.08 & 0.59 & 0.17 & -0.05 & 0.95 & 1 & 0.59 & 0.50 & 0.15 & 0.11 & 0.14 & -0.02 & 0.02 & -0.07 & 0.07 & -0.24 & -0.21 & -0.05 & 0.17 & 0.03 & 0.16 \\
\hline 10 & 0.07 & 0.10 & 0.02 & 0.06 & 0.35 & 0.08 & -0.09 & 0.63 & 0.59 & 1 & 0.40 & -0.05 & -0.08 & -0.38 & -0.01 & 0.01 & 0.18 & -0.06 & -0.24 & -0.21 & -0.17 & -0.21 & -0.20 & -0.25 \\
\hline 11 & -0.06 & -0.04 & -0.17 & -0.02 & 0.28 & 0.09 & -0.18 & 0.56 & 0.50 & 0.40 & 1 & 0.04 & 0.00 & 0.19 & 0.01 & 0.03 & -0.07 & -0.03 & -0.13 & -0.13 & 0.11 & 0.06 & -0.05 & 0.04 \\
\hline 12 & -0.64 & -0.52 & -0.12 & -0.01 & 0.01 & 0.00 & 0.03 & 0.10 & 0.15 & -0.05 & 0.04 & 1 & -0.14 & 0.07 & -0.03 & 0.00 & -0.05 & -0.04 & -0.01 & -0.03 & 0.04 & 0.13 & 0.10 & 0.13 \\
\hline 13 & -0.05 & -0.32 & -0.09 & -0.04 & 0.01 & 0.00 & 0.04 & 0.07 & 0.11 & -0.08 & 0.00 & -0.14 & 1 & 0.07 & -0.04 & -0.01 & -0.04 & 0.00 & -0.03 & -0.03 & 0.05 & 0.09 & 0.07 & 0.09 \\
\hline 14 & -0.12 & -0.14 & -0.12 & -0.09 & 0.11 & 0.06 & 0.02 & 0.15 & 0.14 & -0.38 & 0.19 & 0.07 & 0.07 & 1 & 0.14 & -0.07 & -0.36 & 0.05 & 0.04 & 0.26 & 0.0 & 0.49 & 0.29 & 0.50 \\
\hline 15 & 0.04 & 0.05 & 0.06 & 0.03 & 0.03 & 0.00 & -0.06 & -0.01 & -0.02 & -0.01 & 0.01 & -0.03 & -0.04 & 0.14 & 1 & -0.09 & 0.37 & 0.00 & -0.01 & -0.04 & 0.05 & -0.11 & -0.05 & -0.11 \\
\hline 16 & 0.00 & 0.00 & 0.02 & 0.02 & 0.01 & 0.00 & -0.04 & 0.01 & 0.02 & 0.01 & 0.03 & 0.00 & -0.01 & -0.07 & -0.09 & 1 & 0.00 & 0.00 & 0.00 & -0.02 & 0.04 & -0.01 & -0.02 & -0.02 \\
\hline 17 & 0.06 & 0.07 & 0.07 & 0.07 & -0.03 & -0.02 & -0.05 & -0.06 & -0.07 & 0.18 & -0.07 & -0.05 & -0.04 & -0.36 & 0.37 & 0.00 & 1 & -0.04 & -0.02 & -0.12 & 0.02 & -0.23 & -0.13 & -0.24 \\
\hline 18 & -0.13 & -0.25 & -0.08 & 0.00 & 0.01 & 0.00 & 0.04 & 0.08 & 0.07 & -0.06 & -0.03 & -0.04 & 0.00 & 0.05 & 0.00 & 0.00 & -0.04 & 1 & -0.04 & -0.04 & 0.06 & 0.08 & 0.06 & 0.08 \\
\hline 19 & 0.03 & 0.04 & -0.11 & 0.01 & -0.16 & -0.05 & 0.01 & -0.16 & -0.24 & -0.24 & -0.13 & -0.01 & -0.03 & 0.04 & -0.01 & 0.00 & -0.02 & -0.04 & 1 & 0.10 & 0.16 & 0.03 & 0.02 & 0.06 \\
\hline 20 & 0.12 & 0.12 & 0.02 & 0.04 & -0.01 & 0.03 & 0.11 & -0.20 & -0.21 & -0.21 & -0.13 & -0.03 & -0.03 & 0.26 & -0.04 & -0.02 & -0.12 & -0.04 & 0.10 & 1 & 0.03 & 0.49 & 0.42 & 0.47 \\
\hline 21 & -0.03 & -0.06 & -0.20 & 0.11 & -0.14 & -0.04 & 0.23 & -0.02 & -0.05 & -0.17 & 0.11 & 0.04 & 0.05 & 0.01 & 0.05 & 0.04 & 0.02 & 0.06 & 0.16 & 0.03 & 1 & 0.18 & 0.27 & 0.19 \\
\hline 22 & -0.25 & -0.28 & -0.27 & 0.03 & 0.01 & 0.03 & 0.13 & 0.15 & 0.17 & -0.21 & 0.06 & 0.13 & 0.09 & 0.49 & -0.11 & -0.01 & -0.23 & 0.08 & 0.03 & 0.49 & 0.18 & 1 & 0.78 & 0.97 \\
\hline 23 & -0.18 & -0.21 & -0.23 & 0.04 & -0.16 & -0.04 & 0.14 & 0.01 & 0.03 & -0.20 & -0.05 & 0.10 & 0.07 & 0.29 & -0.05 & -0.02 & -0.13 & 0.06 & 0.02 & 0.42 & 0.27 & 0.78 & 1 & 0.74 \\
\hline 24 & -0.23 & -0.26 & -0.26 & 0.03 & 0.01 & 0.03 & 0.12 & 0.14 & 0.16 & -0.25 & 0.04 & 0.13 & 0.09 & 0.50 & -0.11 & -0.02 & -0.24 & 0.08 & 0.06 & 0.47 & 0.19 & 0.97 & 0.74 & 1 \\
\hline
\end{tabular}

Source: Author's own computation. 
The size of the company is negatively correlated with the indebtedness rates, as well as the tangibility, which from a statistical point of view, shows that the companies have fixed assets with an average proportion of $30 \%$. The sales growth rate is positively correlated with the total indebtedness rate, respectively on the long term and negative with the short term one. Although the technology sector is a sector in continuous development, registering very high growths, the median shows that the growth rate is at the level of $10 \%$. The median of the variable working capital fund suggests that most companies have a financial balance, managing to finance their fixed assets from permanent capital.

The corporate governance dummy variables have the median 1 , regarding the duality of the CEO it can be said that the CEO is not the chairman of the board of directors, regarding the presence of the three committees, remuneration, audit and nomination, we can also affirm in this is the case that most companies have these committees in their structure, with the average number of board members being around 8 . These are negatively correlated with debt ratios.

Macroeconomic indicators such as interest rate, inflation rate and market size are positively correlated with debt ratios, only the gross domestic product per capita is negatively correlated with them.

\subsection{The Outcomes of Panel Data Regression Models}

After analyzing the influence of the variables, placed in different models, on the three dependent variables, we can say whether we accept or reject the hypotheses that have been initially formulated. Based on the outcomes out of Table 5, the working capital and the inflation rate variables have a statistically negative but insignificant relationship with the dependent variables. The first hypothesis states that there is a positive relationship between the size of the company and the indebtedness rates, the results of the regressions showed that there is a negative relation, so we can conclude that we reject H1. The second hypothesis states that there is a positive relationship between tangibility of assets and indebtedness rates, the results of the regressions showed that there is a positive relation with the total indebtedness rate and with the long-term indebtedness rate, and negative with the long-term indebtedness rate in short, so we can accept $\mathrm{H} 2$.

The third hypothesis argues that there is a negative relationship between growth opportunity and debt, results of regressions showing that growth opportunity is in a positive relationship with the total and long-term debt ratio, and a negative relationship with the short-term one. In short, we can reject $\mathrm{H} 3$. The fourth hypothesis states that there is a negative relationship between liquidity and debt while the results of the regressions have shown that there is a negative relationship with all three rates, thus $\mathrm{H} 4$ is accepted. Hypothesis 5 states that there is a positive relationship between the effective tax rate and indebtedness, the results of the regressions showed that there is a negative relationship, thus, H5 is rejected. Theoretically, a company that has a high effective tax rate will benefit, by contracting debts, from maximizing the tax deduction. In our case, the negative relationship can be explained by the fact that companies with long-term debt have a reduced effective rate.

The sixth hypothesis argues that there is a negative relationship between financial return and debt, the coefficient came out negative in relation to all debt rates, so $\mathrm{H} 6$ can be accepted. The negative coefficient of ROE underlines that the debt rate decreases as profitability increases, so companies follow the theory of hierarchical financing sources, using profit first to finance operations, and then debt. The following hypothesis states that there is a negative relationship between the rate of inflation and debt. The coefficient came out negative in relation to the total and long-term debt rate, and positive to the short-term debt rate, so we can accept H7. Hypothesis 8 states that there is a negative relationship between the annual interest rate and debt, the results of the regressions showed a positive relationship, so $\mathrm{H} 8$ is rejected. 
Table 5. Estimated coefficients for all three models.

\begin{tabular}{|c|c|c|c|c|c|c|c|c|c|}
\hline \multirow{2}{*}{ Variable } & \multicolumn{3}{|c|}{ (1) } & \multicolumn{3}{|c|}{ (2) } & \multicolumn{3}{|c|}{ (3) } \\
\hline & TD & LTD & STD & TD & LTD & STD & TD & LTD & STD \\
\hline Growth & & & & & & & $\begin{array}{l}0.002 \\
(1.05)\end{array}$ & $\begin{array}{l}0.002 \\
(0.78)\end{array}$ & $\begin{array}{c}-0.0006 \\
(-1.02)\end{array}$ \\
\hline Depr & $\begin{array}{c}1.77 \times \\
10^{-6 * * *} \\
(4.17)\end{array}$ & $\begin{array}{c}2.29 \times \\
10^{-6 * * *} \\
(4.44)\end{array}$ & $\begin{array}{c}-4.71 \times \\
10^{-8} \\
(-0.33)\end{array}$ & & & & & & \\
\hline WC & $\begin{array}{c}-1.47 \times \\
10^{-9} \\
(-0.17)\end{array}$ & $\begin{array}{c}-1.80 \times \\
10^{-9} \\
(-0.17)\end{array}$ & $\begin{array}{c}2.16 \times \\
10^{-10} \\
(-0.07)\end{array}$ & & & & & & \\
\hline Liq & & & & $\begin{array}{c}-0.027^{*} \\
(-2.50)\end{array}$ & $\begin{array}{l}-0.03^{* *} \\
(-2.18)\end{array}$ & $\begin{array}{c}-0.02 * * * \\
(-7.72)\end{array}$ & & & \\
\hline Prop & $\begin{array}{c}-0.10^{* * *} \\
(-7.49)\end{array}$ & $\begin{array}{c}-0.14^{* * *} \\
(-8.23)\end{array}$ & $\begin{array}{l}-0.009 * \\
(-2.05)\end{array}$ & & & & & & \\
\hline Size & & & & & & & $\begin{array}{c}-0.08^{* * *} \\
(-4.62)\end{array}$ & $\begin{array}{c}-0.10^{* * *} \\
(-5.44)\end{array}$ & $\begin{array}{c}-0.02^{* * *} \\
(-4.98)\end{array}$ \\
\hline M_size & & & & $\begin{array}{c}381.07^{* * *} \\
(4.04)\end{array}$ & $\begin{array}{c}713.10 \\
(1.41)\end{array}$ & $\begin{array}{l}210.07 * \\
(-1.98)\end{array}$ & & & \\
\hline Board & & & & & & & $\begin{array}{c}0.03 \\
(1.43)\end{array}$ & $\begin{array}{l}0.05 * \\
(2.26)\end{array}$ & $\begin{array}{c}0.008 \\
(-1.43) \\
\end{array}$ \\
\hline PBV & $\begin{array}{c}-0.003 * * * \\
(-21.56) \\
\end{array}$ & $\begin{array}{c}-0.0033 \\
* * * \\
(-15.99) \\
\end{array}$ & $\begin{array}{c}-0.000121 \\
* \\
(-2.14)\end{array}$ & & & & & & \\
\hline PER & & & & & & & $\begin{array}{c}-0.000141 \\
* * * \\
(-12.46) \\
\end{array}$ & $\begin{array}{c}-0.000127 \\
* * * \\
(-8.40) \\
\end{array}$ & $\begin{array}{c}-6.42 \times \\
10^{-6 *} \\
(-1.90)\end{array}$ \\
\hline GDP_cap & & & & $\begin{array}{c}-2.24 \times \\
10^{-5 *} \\
(-2.54)\end{array}$ & $\begin{array}{l}-2.19 \times \\
10^{-5 * *} \\
(-2.92)\end{array}$ & $\begin{array}{c}-6.31 \times \\
10^{-6 * *} \\
(-3.00)\end{array}$ & & & \\
\hline Int_r & & & & $\begin{array}{c}6.51 \\
(1.28)\end{array}$ & $\begin{array}{l}9.50 * \\
(1.65)\end{array}$ & $\begin{array}{c}-6.31 \times \\
10^{-6 * *} \\
(-3.00)\end{array}$ & & & \\
\hline Etax & & & & & & & $\begin{array}{c}-1.95 \times \\
10^{-5} \\
(-0.008)\end{array}$ & $\begin{array}{c}-0.0003 \\
(-0.14)\end{array}$ & $\begin{array}{l}-0.003 \\
(-0.62)\end{array}$ \\
\hline Inf_r & $\begin{array}{c}-2.16 \\
(-0.70) \\
\end{array}$ & $\begin{array}{c}-1.82 \\
(-0.48) \\
\end{array}$ & $\begin{array}{c}0.11 \\
(0.10) \\
\end{array}$ & & & & & & \\
\hline ROE & $\begin{array}{l}-5.09 \times \\
10^{-5 * * *} \\
(-4.89)\end{array}$ & $\begin{array}{c}-0.000103 \\
* * * \\
(-8.15) \\
\end{array}$ & $\begin{array}{c}-5.30 \times \\
10^{-6} \\
(-1.53)\end{array}$ & & & & & & \\
\hline Stock & & & & & & & $\begin{array}{c}0.0003 \\
(0.35)\end{array}$ & $\begin{array}{c}0.0006 \\
(0.71)\end{array}$ & $\begin{array}{c}-0.0008 \\
* * * \\
(-4.05) \\
\end{array}$ \\
\hline S_Ceo & & & & $\begin{array}{c}0.76^{* * *} \\
(6.62)\end{array}$ & $\begin{array}{c}0.94^{* * *} \\
(7.22)\end{array}$ & $\begin{array}{c}0.09 * * * \\
(3.62)\end{array}$ & & & \\
\hline Tang & & & & $\begin{array}{l}0.37^{* *} \\
(2.85)\end{array}$ & $\begin{array}{l}0.33 * \\
(2.32)\end{array}$ & $\begin{array}{l}-0.10 * \\
(-2.49)\end{array}$ & & & \\
\hline C_a & $\begin{array}{c}-0.32^{* * *} \\
(-4.28)\end{array}$ & $\begin{array}{c}-0.46^{* * *} \\
(-4.98)\end{array}$ & $\begin{array}{c}-0.15^{* * *} \\
(-6.02)\end{array}$ & & & & & & \\
\hline C_n & & & & $\begin{array}{l}0.63 * * * \\
(-6.15)\end{array}$ & $\begin{array}{c}-0.77^{* * *} \\
(-6.54)\end{array}$ & $\begin{array}{c}-0.11^{* * *} \\
(-4.78)\end{array}$ & & & \\
\hline C_r & & & & & & & $\begin{array}{c}0.03 \\
(1.43)\end{array}$ & $\begin{array}{l}0.05 * \\
(2.26)\end{array}$ & $\begin{array}{c}0.008 \\
(-1.43)\end{array}$ \\
\hline $\mathrm{R}^{2}$ & 0.49 & 0.43 & 0.089 & 0.099 & 0.12 & 0.16 & 0.08 & 0.199 & 0.14 \\
\hline F-statistic & $98.71^{* * *}$ & $76.05^{* * *}$ & $9.96^{* * *}$ & $11.17^{* * *}$ & $13.86^{* * *}$ & $19.80^{* * *}$ & $9.69 * * *$ & $24.67^{* * *}$ & $16.74^{* * *}$ \\
\hline
\end{tabular}


Hypothesis 9 argues that there is a positive relationship between the gross domestic product per capita and debt, the results of the regressions showed a negative relation with all the three rates of debt, so H9 is rejected. The latter hypothesis argues that there is a negative relationship between governance and debt indicators. The audit, remuneration and nomination committees are in a negative relationship with all three indebtedness rates, so H11, H12 and H13 are accepted. The status of the CEO is in a positive relationship, so Hypothesis 14 is rejected. Between board size and debt ratio is a positive relationship, $\mathrm{H} 10$ is rejected. The presence of the audit committee in the company structure signifies an efficient control of internal processes and activities, as well as combating information asymmetry, resulting in the reduction of agency costs. The presence of the nomination committee in the organizational structure of the company helps to nominate capable people in the management structure, who take decisions that do not lead to increasing debt when looking for alternative funding sources. The presence of the remuneration committee can lead to effective decisions to motivate and ambition the board directors so that they can run the company efficiently without suffocating it in debt. The CEO's status is in a positive relationship with the dependent variable, the fact that the CEO is or is not the president, has an impact on the debt.

The Prop variable which measures the size of the company and is calculated as a natural logarithm of the turnover, is in a significantly negative relation with the indebtedness rates and respects the principles of pecking order theory. Thus, with the increase in size, the company will use in the first phase, as a source of financing, its own earnings. Depreciation is in a positive and significant relationship with the long-term and total indebtedness rate and in an insignificant relationship with the short-term indebtedness rate. Price to book value has a significant negative impact on indebtedness rates, so when this indicator increases, it means that the value of the market shares compared to the book value increases, and the investments will be financed by the shareholders, which leads to the reduction of bank loans. The size of the market, a variable calculated as a ratio between market capitalization and gross domestic product, is in a positive and significant relationship with the total indebtedness rate, respectively with the short term rate, suggesting that easy access on the market to financial sources, information, etc., allows companies to access new sources of external financing, such as the issue of shares or bank loans. The more developed the market, in our case, the technology services and information industry, the more the companies are inclined to turn to external sources to support their short-term operations. In relation to the long-term debt ratio, a statistically insignificant relationship resulted. Price to earnings ratio is in a statistically negative and significant relationship with all three debt ratios. Thus, when a company borrows from banks, for example, it will have to pay interests, and this will lead to a decrease in the net result of the firm, and implicitly of the PER. It is also true that depending on what purpose the debt is made, if it is done with the purpose of making a strategic investment, acquiring another company for example, this will have a positive influence on the PER. The duration of the stock rotation has a positive coefficient, but it is insignificant, except for the short-term debt ratio, in relation to which it is in a significant relationship. A positive relationship between this and the dependent variable can be explained by the fact that a longer duration of stock exit means that the sales are not very high and the company has to borrow in order to support its expenses.

\section{Concluding Remarks}

The purpose of this paper was to investigate the main factors which have an influence on financial structure at the enterprise level, using a sample of 51 American companies listed on the New York Stock Exchange. The relationships that were analyzed between debt and the most important factors, promoted by the traditional theories of capital structure, are similar to those which were observed and analyzed in other research papers from previous years. The dependent variables chosen, namely the total indebtedness rate, the long-term indebtedness rate and the short-term indebtedness rate were chosen because they are factors that influence more or less each of the three. The factors were grouped into three categories, company specific factors, macroeconomic factors and corporate governance factors. These factors have an impact that can be more or less significant. It was demonstrated once 
again that factors such as tangibility, growth, size, liquidity etc. have an important influence on the financial structure. In conclusion, the results of the analysis show that the principles of the pecking order theory apply in this case, because the tendency of firms is to be financed internally rather than externally. External finance is also a possibility, but as soon as the internal funds become available, the companies prefer to use them.

This work is limited because the database consists of 51 companies and for a relatively short period of time. The companies were taken from only one sector of activity and only from one country, and this limits the applicability. Future research that includes more countries and a larger sample of companies would better explain the determinants, as, as we have seen, there are also country-specific factors that influence decisions in choosing the optimal financial structure.

Author Contributions: Conceptualization, G.V., S.C.G. and D.A.T.; Data curation, G.V., S.C.G. and D.A.T.; Formal analysis, G.V., S..C.G. and D.A.T.; Funding acquisition, G.V., Ş.C.G. and D.A.T.; Investigation, G.V., S.C.G. and D.A.T.; Methodology, G.V., S..C.G. and D.A.T.; Project administration, G.V., S..C.G. and D.A.T.; Resources, G.V., S..C.G. and D.A.T.; Software, G.V., Ş.C.G. and D.A.T.; Supervision, G.V., Ş.C.G. and D.A.T.; Validation, G.V., S..C.G. and D.A.T.; Visualization, G.V., Ş.C.G. and D.A.T.; Writing—original draft, G.V., Ş.C.G. and D.A.T.; Writing一review \& editing, G.V., S..C.G. and D.A.T.

Funding: This research received no external funding.

Conflicts of Interest: The authors declare no conflict of interest.

\section{References}

Alipour, Mohammad, Mir Farhad Seddigh Mohammadi, and Hojjatollah Derakhshan. 2015. Determinants of capital structure: An empirical study of firms in Iran. International Journal of Law and Management 57: 53-83. [CrossRef]

Amidu, Mohammed. 2007. Determinants of capital structure of banks in Ghana: An empirical approach. Baltic Journal of Management 2: 67-79. [CrossRef]

Ang, James S., Jess H. Chua, and John J. McConnell. 1982. The Administrative Costs of Corporate Bankruptcy: A Note. The Journal of Finance 37: 219-226. [CrossRef]

Auerbach, Alan J. 1985. Real Determinants of Corporate Leverage. In Corporate Capital Structures in the United States. Edited by Benjamin M. Friedman. Chicago: University of Chicago Press, pp. 301-24.

Baker, Malcolm, and Jeffrey Wurgler. 2002. Market timing and capital structure. Journal of Finance 57: 1-32. [CrossRef]

Bartholdy, Jan, and Cesario Mateus. 2008. Taxes and Corporate Debt Policy: Evidence for Unlisted Firms of Sixteen European Countries. SSRN. [CrossRef]

Barton, Sidney L., Ned C. Hill, and Srinivasan Sundaram. 1989. An Empirical-Test of Stakeholder Theory Predictions of Capital Structure. Financial Management 18: 36-44. [CrossRef]

Bas, Tugba, Gulnur Muradoglu, and Kate Phylaktis. 2010. Determinants of capital structure in developing countries. Paper presented at the European Financial Management Symposium 2010, Beijing, China, April 22-24.

Bokpin, Godfred Alufar. 2009. Macroeconomic development and capital structure decisions of firms: Evidence from emerging market economies. Studies in Economics and Finance 26: 129-42. [CrossRef]

Buvanendra, Shantharuby, P. Sridharan, and S. Thiyagarajan. 2017. Firm characteristics, corporate governance and capital structure adjustments: A comparative study of listed firms in Sri Lanka and India. IIMB Management Review 29: 245-58. [CrossRef]

Chadha, Saurabh, and Anil K. Sharma. 2015. Determinants of capital structure: An empirical evaluation from India. Journal of Advances in Management Research 12: 3-14. [CrossRef]

Chaklader, Barnali, and Deepak Chawla. 2016. A Study of Determinants of Capital Structure through Panel Data Analysis of Firms Listed in NSE CNX 500. Vision: The Journal of Business Perspective 20: 267-77. [CrossRef]

Chittenden, Francis, Graham Hall, and Patrick Hutchinson. 1996. Small firm growth, access to capital markets and financial structure: Review of issues and an empirical investigation. Small Business Economics 8: 59-67. [CrossRef] 
Cortez, Michael Angelo, and Stevie Susanto. 2012. The Determinants of Corporate Captal Structure: Evidence from Japanese Manufacturing Companies. Journal of International Business Research 11: 121-34.

Demirgüç-Kunt, Asli, and Vojislav Maksimovic. 1996. Stock market development and financing choices of firms. World Bank Economic Review 10: 341-69. [CrossRef]

Demirgüç-Kunt, Asli, and Vojislav Maksimovic. 1999. Institutions, financial markets, and firm debt maturity. Journal of Financial Economics 54: 295-336. [CrossRef]

Eldomiaty, Tarek I., and Mohamed H. Azim. 2008. The dynamics of capital structure and heterogeneous systematic risk classes in Egypt. International Journal of Emerging Markets 3: 7-37. [CrossRef]

Eriotis, Nikolaos, Dimitrios Vasiliou, and Zoe Ventoura-Neokosmidi. 2007. How firm characteristics affect capital structure: An empirical study. Managerial Finance 33: 321-31. [CrossRef]

Ezeoha, Abel Ebel. 2008. Firm size and corporate financial-leverage choice in a developing economy: Evidence from Nigeria. Journal of Risk Finance 9: 351-64. [CrossRef]

Graham, John R. 1996. Debt and the marginal tax rate. Journal of Financial Economics 41: 41-73. [CrossRef]

Hall, Graham C., Patrick J. Hutchinson, and Nicos Michaelas. 2004. Determinants of the Capital Structures of European SMEs. Journal of Business Finance \& Accounting 31: 711-28. [CrossRef]

Iwaki, Hiromichi. 2019. The effect of debt market imperfection on capital structure and investment: Evidence from the 2008 global financial crisis in Japan. The Quarterly Review of Economics and Finance. [CrossRef]

Jensen, Michael C., and William H. Meckling. 1976. Theory of the firm: Managerial behavior, agency costs and ownership structure. Journal of Financial Economics 3: 305-60. [CrossRef]

Jordan, Judith, Julian Lowe, and Peter Taylor. 1997. Strategy, financial policy and technology assets in UK small firms. Journal of Business Finance \& Accounting 25: 55-70.

Karadeniz, Erdinc, Serkan Yilmaz Kandir, Mehmet Balcilar, and Yildirim Beyazit Onal. 2009. Determinants of capital structure: Evidence from Turkish lodging companies. International Journal of Contemporary Hospitality Management 21: 594-609. [CrossRef]

Kraus, Alan, and Robert H. Litzenberger. 1973. A State-Preference Model of Optimal Financial Leverage. The Journal of Finance 28: 911-22. [CrossRef]

Krishnan, V. Sivarama, and R. Charles Moyer. 1996. Determinants of Capital Structure: An Empirical Analysis of Firms in Industrialized Countries. Managerial Finance 22: 39-55. [CrossRef]

Li, Larry, and Silvia Z. Islam. 2019. Firm and industry specific determinants of capital structure: Evidence from the Australian market. International Review of Economics \& Finance 59: 425-37. [CrossRef]

Marsh, Paul. 1982. The Choice between Equity and Debt: An Empirical-Study. Journal of Finance 37: 121-44. [CrossRef]

Michaelas, Nicos, Francis Chittenden, and Panikkos Poutziouris. 1999. Financial policy and capital structure choice in UK SMEs: Empirical evidence from company panel data. Small Business Economics 12: 113-30. [CrossRef]

Modigliani, Franco, and Merton H. Miller. 1958. The Cost of Capital, Corporation Finance and the Theory of Investment. The American Economic Review 48: 261-97.

Modigliani, Franco, and Merton H. Miller. 1963. Corporate Income Taxes and the Cost of Capital: A Correction. The American Economic Review 53: 433-43.

Moradi, Amir, and Elisabeth Paulet. 2019. The firm-specific determinants of capital structure-An empirical analysis of firms before and during the Euro Crisis. Research in International Business and Finance 47: 150-61. [CrossRef]

Myers, Stewart C. 1977. Determinants of Corporate Borrowing. Journal of Financial Economics 5: 147-75. [CrossRef]

Myers, Stewart C., and Nicholas S. Majluf. 1984. Corporate Financing and Investment Decisions When Firms Have Information That Investors Do Not Have. Journal of Financial Economics 13: 187-221. [CrossRef]

Nenu, Elena Alexandra, Georgeta Vintilă, and Ştefan Cristian Gherghina. 2018. The Impact of Capital Structure on Risk and Firm Performance: Empirical Evidence for the Bucharest Stock Exchange Listed Companies. International Journal of Financial Studies 6: 41. [CrossRef]

Ooi, Joseph. 1999. The determinants of capital structure Evidence on UK property companies. Journal of Property Investment $\mathcal{E}$ Finance 17: 464-80. [CrossRef]

Öztekin, Özde, and Mark J. Flannery. 2012. Institutional determinants of capital structure adjustment speeds. Journal of Financial Economics 103: 88-112. [CrossRef] 
Psillaki, Maria, and Nikolaos Daskalakis. 2009. Are the determinants of capital structure country or firm specific? Small Business Economics 33: 319-33. [CrossRef]

Rajan, Raghuram G., and Luigi Zingales. 1995. What do We Know about Capital Structure-Some Evidence from International Data. Journal of Finance 50: 1421-60. [CrossRef]

Ramli, Nur Ainna, Hengky Latan, and Grace T. Solovida. 2019. Determinants of capital structure and firm financial performance-A PLS-SEM approach: Evidence from Malaysia and Indonesia. Quarterly Review of Economics and Finance 71: 148-60. [CrossRef]

Ross, Stephen A. 1977. The Determination of Financial Structure: The Incentive-Signalling Approach. The Bell Journal of Economics 8: 23-40. [CrossRef]

Sheikh, Nadeem Ahmed, and Zongjun Wang. 2012. Effects of corporate governance on capital structure: Empirical evidence from Pakistan. Corporate Governance 12: 629-41. [CrossRef]

Smith, Clifford W., Jr., and Jerold B. Warner. 1979. Bankruptcy, Secured Debt, and Optimal Capital Structure: Comment. The Journal of Finance 34: 247-51. [CrossRef]

Song, Han-Suck. 2005. Capital Structure Determinants. An Empirical Study of Swedish Companies. Electronic Working Paper Series; CESIS, Stockholm, Sweden: The Royal Institute of Technology.

Stulz, René M., and Herb Johnson. 1985. An Analysis of Secured Debt. Journal of Financial Economics 14: 501-21. [CrossRef]

Su, Larry D. 2010. Ownership structure, corporate diversification and capital structure Evidence from China's publicly listed firms. Management Decision 48: 314-39. [CrossRef]

Titman, Sheridan, and Roberto Wessels. 1988. The Determinants of Capital Structure Choice. Journal of Finance 43: 1-19. [CrossRef]

van der Wijst, Nico, and Roy Thurik. 1993. Determinants of Small Firm Debt Ratios-An Analysis of Retail Panel Data. Small Business Economics 5: 55-65. [CrossRef]

Vintilă, Georgeta, and Stefan Cristian Gherghina. 2012. An Empirical Investigation of the Relationship between Corporate Governance Mechanisms, CEO Characteristics and Listed Companies' Performance. International Business Research 5: 175-91. [CrossRef]

Viviani, Jean-Laurent. 2008. Capital structure determinants: An empirical study of French companies in the wine industry. International Journal of Wine Business Research 20: 171-94. [CrossRef]

(C) 2019 by the authors. Licensee MDPI, Basel, Switzerland. This article is an open access article distributed under the terms and conditions of the Creative Commons Attribution (CC BY) license (http://creativecommons.org/licenses/by/4.0/). 